\title{
Composition, diversity and structure of vascular epiphytes in two contrasting Central Amazonian floodplain ecosystems
}

\author{
Adriano C. Quaresma", Maria Teresa F. Piedade1, Yuri Oliveira Feitosa', Florian Wittmann² and Hans ter Steege ${ }^{3,4}$
}

Received: April 26, 2017

Accepted: July 10, 2017

\begin{abstract}
Research focusing on assemblages of vascular epiphytes in the Amazon are scarce. This is especially true for Amazonian floodplain forests, for which only two previous studies have been published. We compared composition, richness and structure of epiphyte assemblages in white-water and black-water floodplains (várzea and igapó) in Central Amazonia in order to close knowledge gaps concerning the distribution and richness of epiphytes. We established sixteen 25x25 m plots in each forest type, and counted and identified all species of vascular epiphytes occurring on trees with a diameter at breast height $(\mathrm{DBH}) \geq 10 \mathrm{~cm}$. We observed a clear distinction in epiphytic species composition $\left(r^{2}=0.83, p=0.001\right)$ and diversity $(t=3.24, P=0.003)$ between the two environments, with $61.5 \%$ of species being restricted to várzea, $22.9 \%$ restricted to igapó and only $15.6 \%$ common to both ecosystems. The floodplains were also structurally different for the most abundant species and those with the highest Epiphytic Importance Value (IVe). The diversity of trees did not influence the epiphyte diversity in either ecosystem. The forests were found to differ in the composition, diversity and structure of their epiphytic assemblages, which must be taken into account when designing conservation action plans for these ecosystems and for their vascular epiphytes.
\end{abstract}

Keywords: Amazon, biodiversity, floodplains, igapó forests, várzea forests

\section{Introduction}

Vascular epiphytes are characterized by using a mechanical host only for support and to reach areas with higher levels of solar radiation. Consequently, they are independent from the soil in terms of physical support, water and nutrient uptake, either during their entire life (holoepiphytes) or during part of it (hemiepiphytes) (Mueller-Dombois \& Ellenberg 1974; Benzing 1990; Zotz 2013). Globally, there are some 27,614 known species of epiphytes, with a notably greater diversity in the tropical Americas (Zotz 2013), where more than 100 species can be found on a single host tree (Schuettpelz \& Trapnell 2006).

In the Brazilian Amazon research on vascular epiphytes is mostly concentrated in upland forests (Irume et al. 2013; Boelter et al. 2014). However, even in these environments, vascular epiphytes are neglected in conservation action plans, which mostly focus on arboreal species (Obermüller et al. 2012). Epiphytes are also poorly sampled in other Amazonian environments, including savannas (Gottsberger \& Morawetz 1993), coastal forests (Quaresma \& Jardim 2014) and white-sand forests (Steege \& Cornelissen 1989; Mari et al. 2016)

\footnotetext{
${ }^{1}$ Grupo MAUA, Instituto Nacional de Pesquisas da Amazônia, Av. André Araújo, 2936 , Petrópolis, 69067-375, Manaus, AM, Brazil

${ }^{2}$ Department of Biogeochemistry, Max Planck Institute for Chemistry, Hahn-Meiner Weg 1, 55128 Mainz, Germany

${ }^{3}$ Naturalis Biodiversity Center, Vondellaan 55, Postbus 9517, 2300 RA Leiden, The Netherlands

${ }^{4}$ Coordenação de Botânica, Museu Paraense Emílio Goeldi, Av. Magalhães Barata 376, P.O. Box 399, 66040-170, Belém, PA, Brazil

* Corresponding author: acq.quaresma@gmail.com
} 
While vascular epiphytes are visually highly abundant in Amazonian floodplain forests, to the best of our knowledge there are only two studies that investigated species composition and richness. Nieder et al. (2000), in 1.5 ha of a igapó forest along of the Suromoni River, Venezuelan Amazon, reported 778 individuals belonging to 53 epiphyte species, where orchids (19 species) and aroids (15 species) were the most abundant families. In another study conducted in 0.3 ha of várzea of Colombian Amazon, Benavides et al. (2011) also found orchids and aroids to be the most representative families. This scarcity of studies hampers proper management and conservation measures for forestry ecosystems and their epiphyte assemblages. But it is much more serious, because it hampers our understanding of ecosystem functioning.

White-water floodplain forests (várzea) and blackwater floodplain forests (igapó) (sensu Prance 1979) cover more than $600,000 \mathrm{~km}^{2}$ in the Amazon (Melack \& Hess 2010) and are classified based on the physicalchemical features of their waters. Várzeas are flooded by river waters with high concentrations of nutrients, while igapós are flooded by river waters of low concentration of minerals (Sioli 1984). The difference in fertility is mirrored by tree species richness; in Central Amazonia, várzea forests are comparatively species rich (with up to 100 species ha-1), while igapo forests are comparatively species poor (with up to 60 species ha ${ }^{-1}$ ) (trees $\geq 10 \mathrm{~cm} \mathrm{dbh)} \mathrm{(Wittmann} \mathrm{et} \mathrm{al.} \mathrm{2010;}$ Montero et al. 2012). However, these environments are similar in that both are seasonally flooded during the high water (aquatic) phase, and are seasonally dry during the low water (terrestrial) phase (Junk et al. 1989). This flood pulse is generally regarded as the main driving force determining patterns of tree species composition in these forests (Junk et al. 1989; 2011; Wittmann et al. 2004; 2006).

Though there have been several floristic inventories and ecological analyses of Central Amazonian floodplain forests (collated in Junk et al. 2010), none inventoried epiphytes. Tree species similarity between igapó and várzea is low due, mainly, to differences of soil nutrients (Wittmann et al. 2010). Each tree species is, in theory, a potentially different niche for epiphytes colonization, because of its size, architecture, chemistry, bark roughness, and phenology. On the other hand, the majority of epiphytes are not connected to the soil as are their arboreal hosts. So, we hypothesize that the epiphyte assemblages will show much higher similarity between ecosystems than do trees.

In this study, we compare the composition, diversity and structure of epiphyte assemblages in two contrasting floodplain ecosystems (várzea and igapó) in the Central Amazon, in order to verify whether the patterns of similarity of vascular epiphyte and trees are concordant, and also to analyze if the tree diversity influences the diversity of epiphytes. Várzea and igapó are the most extensive seasonally-flooded ecosystems in the Amazon, nevertheless, they have long been under anthropogenic pressure from housing construction direct clearance and timber extraction, plant and animal husbandry and illegal logging.

\section{Materials and methods}

\section{Study Area}

We conducted our study in a várzea forest at the Mamirauá Reserve for Sustainable Development (RDS) and an igapó forest in Jaú National Park (Parna) (Fig. 1). We selected these study areas because both have well-conserved floodplain forests and reliable inventories for their arboreal species ( $\geq 10 \mathrm{~cm} \mathrm{dbh})$ were available in the database of the INPA-Max Planck project and PELD MAUA Amazonian Humid Areas program.

\section{Jaú National Park (Parna) - Igapó forest}

The Jaú National Park ( $\left.1^{\circ} 90^{\prime} \mathrm{S}-3^{\circ} 00^{\prime} \mathrm{S} 61^{\circ} 25^{\prime} \mathrm{W} \pm 63^{\circ} 50^{\prime} \mathrm{W}\right)$ covers an area of approximately $22,720 \mathrm{~km}^{2}$, and is drained by the Jaú and Unini rivers, which are right bank tributaries of the Rio Negro (Ferreira 2000). Mean annual temperature is $26.7^{\circ} \mathrm{C}$, and mean annual precipitation amounts to 2,300 $\mathrm{mm}$. The rainy season occurs from December to May and the dry season from June to September. The flooding cycle is monomodal, with a mean annual amplitude of $8.17 \mathrm{~m}$; highest water levels occur in June and July, and lowest in October and November (Ferreira 2000). The soil is derived from ancient tertiary sediments, with high levels of kaolinitic clay soils and large areas covered by white sands (podzols) (Junk et al. 2015).

Aguiar (2015) inventoried nine hectares in igapó forests of the Jau River and recorded 6,992 tree individuals $\geq 10$ $\mathrm{cm}$ dbh, belonging to 193 tree species. The most common tree species in climax stage were: Pouteria elegans (A.DC.) Baehni, Amanoa oblongifolia Müll. Arg., Macrolobium acaciifolium (Benth.) Benth., Elvasia quinqueloba Spruce ex Engl., Burdachia sp., Eschweilera tenuifolia (O.Berg) Miers, Duroia velutina Hook.f. ex K.Schum., Swartzia polyphylla DC., Hevea spruceana (Benth.) Müll. Arg. and Erythroxylum spruceanum Peyr.

\section{Mamirauá Sustainable Development Reserve (SDR) - Várzea forest}

Mamirauá SDR is located in the western part of the Central Brazilian Amazon, approximately $30 \mathrm{~km}$ NW of the city of Tefé ( $\left.2^{\circ} 51^{\prime} \mathrm{S} 64^{\circ} 55^{\prime} \mathrm{W}\right)$. The reserve covers an area of approximately $11,240 \mathrm{~km}^{2}$ of várzea forests and is delimited by the Juruá and Amazon/Solimões Rivers and the Auati-Paraná channel (Plano de Gestão 2014). Várzea soils generally have high proportions of silt and fine sand, and often are eutrophic (Irion 1984). 


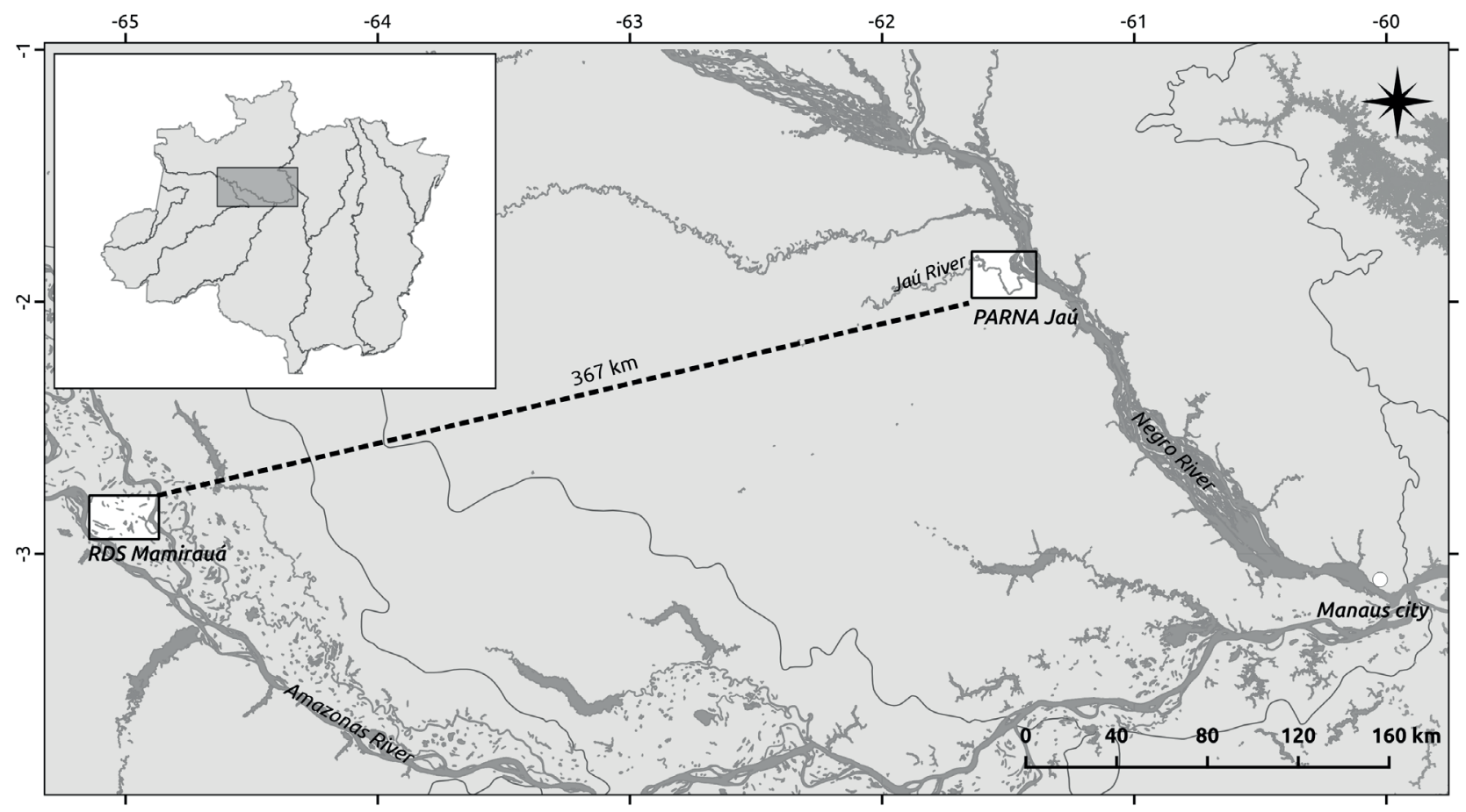

Figure 1. Location map of the study sites in the Reserva de Desenvolvimento Sustentável Mamirauá and Parque Nacional do Jaú.

Wittmann et al. (2002) sampled four hectares of várzea forest in the Mamiraua SDR and recorded 2,080 individuals from 226 tree species. The most common in the climax stage were Cecropia latiloba Miq., Pouteria procera (Mart.) K. Hammer, Oxandra riedeliana R.E. Fries, Pouteria polyphleba Diels (R.E. Fries), Tabebuia barbata (E. Mey.) Sandwith, Mabea nitida Spruce ex. Benth., Hevea spruceana Muell. Arg., Crataeva benthamii Eichl., Malouetia tamaquariana A.D.C., Aspidosperma riedelii Muell. Arg, Guatteriopsis paraensis R.E. Fries.

\section{Data collection}

For epiphyte inventories, we selected 16 plots of 25 x $25 \mathrm{~m}$ within forest plots previously established in each ecosystem - for an inventoried area total of 1 ha in size. Sampling was conducted only in climax forest (see Wittmann et al. 2002; Junk et al. 2015), so that the forest structure was similar. Also, we standardized marking of plots at the same flood level in both environments.

We sampled, counted and identified all individuals of all vascular epiphyte species occurring on trees $\geq 10 \mathrm{~cm} \mathrm{DBH}$. We conducted our sampling with the help of binoculars and a digital camera, searching each host tree from two opposite angles, to avoid counting specimens twice. We also climbed at least four host trees per plot. When possible we climbed the four largest host trees within the plot, to facilitate specimen visualization, count and collecting of epiphytes in the largest possible number of surrounding trees.

For epiphyte species that produce distinct individuals we considered each distinctively isolated group, such as rosettes
(Bromeliaceae), pseudobulbs, stems, rizhomes (Orchidaceae) and stems (Araceae and Clusiaceae) as one individual; for species that occur in colonies (Gesneriaceae and Piperaceae), "clusters of branches" were considered unique when distinctly separated from other individuals on the host tree, So, in both cases have we considered "individuals" groups that were separated from each other (Sanford 1968).

When possible the species were identified in loco, samples fertile or sterile of species were collected for posterior identification using dichotomous keys (Cruz 1994; Cruz \& Braga 1997), specialized books (Ribeiro et al. 1999; Zuquim et al. 2008), comparisons with herbarium material (INPA Herbarium and Herbarium MG) and/or with the help of experts. For a more complete list of vascular epiphytes, we also surveyed trees around the plots for a qualitative assessment. Samples sterile were grown in a greenhouse until the opening of the flowers. Fertile plants are in the process of being incorporated in the INPA Herbarium. We classified species following APG III (2009) and used valid names according to the species list of the Brazilian flora (Flora do Brasil 2020).

The variety of life-form classifications for epiphytes (Benzing 1990) has the potential to confuse (see Zotz 2013). Consequently, we opted to divide epiphytes into ecological life-forms, and classified epiphytes, and classified epiphytes, through literature and also in field observations, as: 1) holo-epiphytes; species that sprout and grow on other plants and never have permanent contact with the soil, and hemi-epiphytes; species that sprout and grow on other plants but subsequently maintain contact with the soil by means of secondary 
roots. In this study we followed Fontoura et al. (2009) and considered species with only two individuals or less per hectare (low abundance) or that only occupies up to two trees (low distribution) rare, and considered species with five or more individuals or groups on trees abundant.

\section{Data analysis}

We used a rarefaction method to compare the number of species found and estimate sampling sufficiency in the two forests (Gotelli \& Colwel 2010). We calculated similarity as the percentage of species exclusive to each environment and the percentage of species that were common to both environments. In order to evaluate the epiphytic composition between the two environments we used a non-metric multidimensional scaling (NMDS), using Bray-Curtis distance for species abundance. We tested the NMDS significance using Analysis of Similarity (ANOSIM).

Alpha diversity of the each epiphyte and tree assemblage was calculated using Fisher's coefficient of diversity (Fisher et al. 1943), including all individuals and species per plot, including distinguishable morpho-species. The Student t test was applied to compare the diversity between two environments. We tested the influence of tree diversity on epiphyte diversity with ANCOVA analysis, using the environments as factor.

We used a rank graph to test the distribution of species abundances in the two assemblages. A quantitative evaluation of epiphyte species was conducted using absolute and relative frequencies on individual host trees (FAi, FRi) and on specific host trees (FAj, FRj); the value of epiphytic importance (IVe) was calculated using both types (FRi and FRj) of relative frequency (Waechter 1998), as follows:

$$
\begin{aligned}
\mathrm{FAi} & =(\mathrm{Nfi} / \mathrm{Nfa}) \cdot 100 \\
\mathrm{FRi} & =(\mathrm{Nf} / \mathrm{N} \text { Nfi).100 } \\
\mathrm{FAj} & =(\mathrm{Sfi} / \mathrm{Sfa}) \cdot 100 \\
\mathrm{FRj} & =(\mathrm{Sf} / \mathrm{\Sigma} \mathrm{Sf}) \cdot 100 \\
\mathrm{IVe} & =(\mathrm{FRi}+\mathrm{FRj}) / 2
\end{aligned}
$$

where, Nfi is the number of host trees occupied by the epiphyte species $i$; Nfa the total number of host trees species in the sample; Sfi the number of host trees occupied by the epiphyte species $i ; \mathrm{Sfa}=$ the total number host trees species in the sample; and IVe the value of epiphytic importance. These parameters translate the species capacity by means of reproduction and dispersion in the environment (FRi), and their capacity to colonize different substrata (FRj), which in turn express themselves in the ecological importance of each species (IVe) (Waechter 1998).

We conducted all analyses in $\mathrm{R}$ ( $\mathrm{R}$ Development Core Team 2011). Anosim and ANCOVA were conducted in the vegan package (vegan: Community Ecology Package 2016); metaMDS in vegan was also used for the NMDS analysis.

\section{Results}

\section{Composition and diversity}

In total and from both environments, we recorded a total of 2,922 individuals, belonging to 96 species, 59 genera and 13 families of epiphytes. Fifty-six (59.3\%) of these were Orchidaceae. Other important families were Araceae (11 species, $11.4 \%$ ) and Polypodiaceae (eight species, $8.3 \%$ ) (Tab. 1). In the várzea forest, we recorded 459 individuals from 132 tree species, of which 181 had 2,968 individuals and 96 species of vascular epiphytes (Fisher's alpha $=18.97$ ), belonging to 13 families, 47 genera and 73 species. In the igapó forest we recorded 662 individuals from 111 tree species, of which 165 trees hosted 653 epiphyte individuals belonging to 9 families, 21 genera and 37 species (Fisher's alpha = 8.6). Orchidaceae dominated in both várzea and igapó (39 and 19 species, respectively), followed by Araceae (nine and five species) and Polypodiaceae (seven and three species).

The rarefaction shows that for the same sample effort, the curve in igapó forest tends to stabilize around 37 species. However, for the várzea forest that sampling effort seemed inadequate and even with a great number of species recorded for the area the rarefaction curve did not tend to stabilization (Fig. 2). In várzea and igapó, $61.5 \%$ and $22.9 \%$ of all recorded species were exclusive, while $15.6 \%$ of all species were common to both environments.

Holo-epiphytism is the predominant life-form (a total of 85 species, $88.6 \%$, in both environments combined: Tab. 1), while 11 (11.4\%) hemi-epiphyte species were found. Holo-epiphytes represented $86.4 \%$ of species in várzea forest and $91.9 \%$ of species in igapó forest. On the other hand, hemi-epiphytes represented $13.6 \%$ of species in várzea forest and $8.1 \%$ in igapó forest.

Fisher's Alpha for epiphytes varied from $1.3 \pm 8.3$ in igapó and $3.2 \pm 8.3$ in várzea (Fig. $3 \mathrm{~A}$ ). For trees the values were $3.4 \pm 25.9$ in igapó and $5.4 \pm 53.2$ in várzea (Fig. 3B). Forests differed in the diversity of both their epiphyte $(\mathrm{t}=3.24, \mathrm{P}=0.003)$ and tree $(\mathrm{t}=2.03, \mathrm{P}=0.05)$ assemblages. However, tree diversity did not explain the diversity of vascular epiphytes in várzea forest $\left(r^{2}=-0.03, P=0.4\right.$, Fig. $3 C)$. While in igapó forest, though it was not significant $\left(\mathrm{r}^{2}=\right.$ $-0.01, \mathrm{P}=0.27$; Fig. $3 \mathrm{D}$ ), it did show a trend.

\section{Structure}

Results show a clear compositional distinction of vascular epiphytes between várzea and igapó forests $\left(r^{2}=0.83, \mathrm{p}<0.001\right)$, as indicated in the first NMDS displaying two well-defined groups (Fig. 4). Both environments are dominated by few, very abundant, species, and many species with a low number of individuals that can be considered as rare (Tab. 2, Fig. 5). Nevertheless, the most abundant species differ between 
Table 1. Floristic composition and life-form of vascular epiphyte assemblages of várzea and igapó forests in Central Amazonia. HM - Hemiepiphytes. HO - Holoepiphytes.

\begin{tabular}{|c|c|c|c|c|}
\hline \multirow{2}{*}{ Family } & \multirow{2}{*}{ Species } & \multicolumn{2}{|c|}{ Habitat } & \multirow{2}{*}{ Life form } \\
\hline & & Várzea & Igapó & \\
\hline \multirow{11}{*}{ Araceae } & Anthurium clavigerum Poepp. & 09 & - & HM \\
\hline & Anthurium bonplandii Bunting & 45 & - & $\mathrm{HO}$ \\
\hline & Anthurium gracile (Rudge) Schott & 45 & 05 & $\mathrm{HO}$ \\
\hline & Anthurium pentaphyllum (Aubl.) G. Don & 02 & 05 & HM \\
\hline & Anthurium sp. & 03 & - & HM \\
\hline & Philodendron sp. & 04 & - & HM \\
\hline & Philodendron acutatum Schott & - & 09 & HM \\
\hline & Philodendron billietiae Croat & 02 & 27 & HM \\
\hline & Philodendron solimoesense A.C.Sm. & 07 & 40 & HM \\
\hline & Philodendron barrosoanum G.S.Bunting & 26 & - & HM \\
\hline & Monstera adansonii Schott & 23 & - & HM \\
\hline \multirow{2}{*}{ Aspleniaceae } & Asplenium angustifolium Michx & 51 & - & $\mathrm{HO}$ \\
\hline & Asplenium serratum L. & 68 & 06 & $\mathrm{HO}$ \\
\hline \multirow{4}{*}{ Bromeliceae } & Aechmea beeriana L.B.Sm. \& M.A.Spencer & 19 & - & $\mathrm{HO}$ \\
\hline & Aechemea mertensii (G.Mey.) Schult. \& Schult.f.* & 01 & 01 & $\mathrm{HO}$ \\
\hline & Aechmea setigera Mart. ex Schult. \& Schult.f. & - & 02 & $\mathrm{HO}$ \\
\hline & Araeococcus micranthus Brongn* & - & 01 & $\mathrm{HO}$ \\
\hline Cactaceae & Epiphyllum sp. & 04 & 01 & $\mathrm{HO}$ \\
\hline Clusiaceae & Clusia sp. & 05 & 13 & HM \\
\hline Cyclantaceae & Cyclantaceae ind. & 01 & - & HM \\
\hline Gesneriaceae & Codonanthopsis crassifolia (H. Focke) Chautems \& M. Perret & 114 & 205 & $\mathrm{HO}$ \\
\hline \multirow{31}{*}{ Orchidaceae } & Codonanthopsis ulei Mansf. & 08 & 11 & $\mathrm{HO}$ \\
\hline & Codonanthopsis sp1 & 05 & - & $\mathrm{HO}$ \\
\hline & Aganisia cyanea (Schltr.) Rchb.f.* & - & 01 & $\mathrm{HO}$ \\
\hline & Bifrenaria sp. & 05 & - & $\mathrm{HO}$ \\
\hline & Brassia sp. & 02 & - & $\mathrm{HO}$ \\
\hline & Brassavola martiana Lindl. & - & 02 & $\mathrm{HO}$ \\
\hline & Caularthron bicornutum (Hook.) Raf. & - & 02 & $\mathrm{HO}$ \\
\hline & Camaridium micranthum M.A. Blanco & 105 & - & $\mathrm{HO}$ \\
\hline & Catasetum sp. & 01 & - & $\mathrm{HO}$ \\
\hline & Cattleya violacea (Kunth) Rolfe & 03 & 05 & $\mathrm{HO}$ \\
\hline & Cohniella cebolleta (Jacq.) Christenson & - & 35 & $\mathrm{HO}$ \\
\hline & Christensonella uncata (Lindl.) Szlach., Mytnik, Górniak \& Śmiszek & 255 & - & $\mathrm{HO}$ \\
\hline & Dickeya sp. & 02 & - & $\mathrm{HO}$ \\
\hline & Dichaea ancoraelabia C. Schweinf. & - & 03 & $\mathrm{HO}$ \\
\hline & Epidendrum coronatum Ruiz \& Pav. & 02 & - & $\mathrm{HO}$ \\
\hline & Epidendrum micronocturnum Carnevali \& G.A.Romero & - & 42 & $\mathrm{HO}$ \\
\hline & Epidendrum nocturnum Jacq. & 09 & 15 & $\mathrm{HO}$ \\
\hline & Epidendrum schlechterianum Ames & 02 & - & $\mathrm{HO}$ \\
\hline & Epidendrum sp. & 04 & - & $\mathrm{HO}$ \\
\hline & Epidendrum strobiliferum Rchb. f. & 31 & - & $\mathrm{HO}$ \\
\hline & Epidendrum rigidum Jacq. & 64 & 08 & $\mathrm{HO}$ \\
\hline & Galeandra devoniana M.R.Schomb. ex Lindl. & - & 13 & $\mathrm{HO}$ \\
\hline & Heterotaxis equitans (Schltr.) Ojeda \& Carnevali & 82 & - & $\mathrm{HO}$ \\
\hline & Maxillaria sp. & 01 & - & $\mathrm{HO}$ \\
\hline & Trichocentrum morenoi (Dodson \& Luer) M.W.Chase \& N.H.Williams & 05 & - & $\mathrm{HO}$ \\
\hline & Octomeria brevifolia Cogn. & - & 40 & $\mathrm{HO}$ \\
\hline & Octomeria sp. & - & 01 & $\mathrm{HO}$ \\
\hline & Orchidaceae 1 & - & 10 & $\mathrm{HO}$ \\
\hline & Orchidaceae 2 & - & 13 & $\mathrm{HO}$ \\
\hline & Orchidaceae 3 & - & 01 & $\mathrm{HO}$ \\
\hline & Orchidaceae 4 & 01 & - & $\mathrm{HO}$ \\
\hline
\end{tabular}


Table 1. Cont.

\begin{tabular}{|c|c|c|c|c|}
\hline \multirow{2}{*}{ Family } & \multirow{2}{*}{ Species } & \multicolumn{2}{|c|}{ Habitat } & \multirow{2}{*}{ Life form } \\
\hline & & Várzea & Igapó & \\
\hline \multirow{27}{*}{ Orchidaceae } & Orchidaceae 5 & 01 & - & $\mathrm{HO}$ \\
\hline & Orchidaceae 6 & 01 & - & $\mathrm{HO}$ \\
\hline & Orchidaceae 7 & 01 & - & $\mathrm{HO}$ \\
\hline & Orleanesia sp1 & - & 23 & $\mathrm{HO}$ \\
\hline & Orleanesia sp2 & 01 & - & $\mathrm{HO}$ \\
\hline & Plectrophora iridifolia (Lodd. ex Lindl.) H.Focke & 01 & - & $\mathrm{HO}$ \\
\hline & Pleorothalis sp. & 66 & - & $\mathrm{HO}$ \\
\hline & Polysthachya sp1 & 07 & - & $\mathrm{HO}$ \\
\hline & Polysthachya sp2 & 01 & - & $\mathrm{HO}$ \\
\hline & Polystachya concreta (Jacq.) Garay \& Sweet & - & 28 & $\mathrm{HO}$ \\
\hline & Polystachya stenophylla Schltr. & - & 52 & $\mathrm{HO}$ \\
\hline & Prosthechea vespa (Vell.) W.E.Higgins & - & 04 & $\mathrm{HO}$ \\
\hline & Prosthechea fragrans (Sw.) W.E.Higgins & 01 & - & $\mathrm{HO}$ \\
\hline & Rudolfiella aurantiaca (Lindl.) Hoehne & - & 01 & $\mathrm{HO}$ \\
\hline & Queketia sp. & 05 & - & $\mathrm{HO}$ \\
\hline & Quekettia microscopica Lindl. & 57 & - & $\mathrm{HO}$ \\
\hline & Scaphyglottis prolifera (R.Br.) Cogn. & 20 & - & $\mathrm{HO}$ \\
\hline & Laelia gloriosa (Rchb.f.) L.O.Williams & 01 & - & $\mathrm{HO}$ \\
\hline & Sobralia sp. & 13 & - & $\mathrm{HO}$ \\
\hline & Aspasia variegata Lindl. & 01 & - & $\mathrm{HO}$ \\
\hline & Specklinia picta (Lindl.) Pridgeon \& M.W.Chase & 127 & - & $\mathrm{HO}$ \\
\hline & Specklinia spiculifera (Lindl.) Pridgeon \& M.W.Chase & 99 & - & $\mathrm{HO}$ \\
\hline & Specklinia grobyi (Batem. ex Lindl.) F.Barros & 23 & - & $\mathrm{HO}$ \\
\hline & Specklinia sp. & 21 & - & $\mathrm{HO}$ \\
\hline & Stelis sp. & 10 & - & $\mathrm{HO}$ \\
\hline & Trigonidium acuminatum Batem. ex Lindl. & 01 & - & $\mathrm{HO}$ \\
\hline & Trigonidium tenue Lodd. & 07 & - & $\mathrm{HO}$ \\
\hline Piperaceae & Peperomia rotundifolia (L.) Kunth & 178 & - & $\mathrm{HO}$ \\
\hline \multirow{9}{*}{ Polypodiaceae } & Peperomia urocarpa Fisch. \& C.A.Mey. & 02 & - & $\mathrm{HO}$ \\
\hline & Campyloneurum angustifolium (Sw.) Fée & 48 & - & $\mathrm{HO}$ \\
\hline & Campyloneurum phyllitidis (L.) C. Presl & 01 & - & $\mathrm{HO}$ \\
\hline & Microgramma sp. & 16 & 01 & $\mathrm{HO}$ \\
\hline & Microgramma baldwinii Brade & - & 19 & $\mathrm{HO}$ \\
\hline & Microgramma megalophylla (Desv.) de la Sota & 08 & 01 & $\mathrm{HO}$ \\
\hline & Microgramma percussa (Cav.) de la Sota & 105 & - & $\mathrm{HO}$ \\
\hline & Microgramma reptans (Cav.) A.R.Sm. & 223 & - & $\mathrm{HO}$ \\
\hline & Pleopeltis polypodioides (L.) Andrews \& Windham & 183 & - & $\mathrm{HO}$ \\
\hline \multirow{3}{*}{ Pteridaceae } & Anetium citrifolium (L.) Splitg. & 21 & - & $\mathrm{HO}$ \\
\hline & Vittaria lineata (L.) Sm. & - & 12 & $\mathrm{HO}$ \\
\hline & Ananthacorus angustifolius (Sw.) Underw. \& Maxon & 01 & - & $\mathrm{HO}$ \\
\hline Lomariopsidaceae & Nephrolepis sp. & 02 & - & $\mathrm{HO}$ \\
\hline \multirow{3}{*}{ Lycopodiaceae } & Phlegmariurus sp. & 01 & - & $\mathrm{HO}$ \\
\hline & Unknown Lycophyte & 01 & - & HO \\
\hline & Total & 2268 & 654 & \\
\hline
\end{tabular}

assemblages; among the 15 overall most abundant species, only Codonanthopsis crassifolia occurred in both forests. Species in the várzea had higher absolute and relative abundance than those in igapó. In várzea, Cristensonela uncata was the most abundant species (255 individuals), followed by Microgramma reptans (223 individuals), Pleopeltis polypodioides (183 individuals), Peperomia retundifolia (178 individuals) and Specklinia picta (127 individuals). In igapó the most abundant species were C. crassifolia (205 individuals), Polysthachya stenophilla (52 individuals), Epidendrum micronocturnum (42 individuals), Octomeria brevifolia (40 individuals) and Philodendron solimoesensis (40 individuals).

Analysis of frequencies and species importance values indicates that the structure of várzea and igapó forests differs considerably (Tab. 1). Only C. crassifolia showed high importance values in both environments, while among 
the 20 most important species, 19 were exclusive to one of the two habitats. The 20 most important species were responsible for $86.7 \%$ of the IVe in várzea and $95 \%$ of the IVe in igapó, indicating that few species have high importance in terms of abundance and colonization of host trees in these forest types.

\section{Discussion}

\section{Composition and diversity}

Studies in Central Amazon floodplain forests have already shown that the number and diversity of tree and herbaceous species are higher in várzea forests than in igapó (i.e. Prance 1979; Ayres 1993; Haugaassen \& Peres 2006; Inuma 2006). This was the case in the present work for

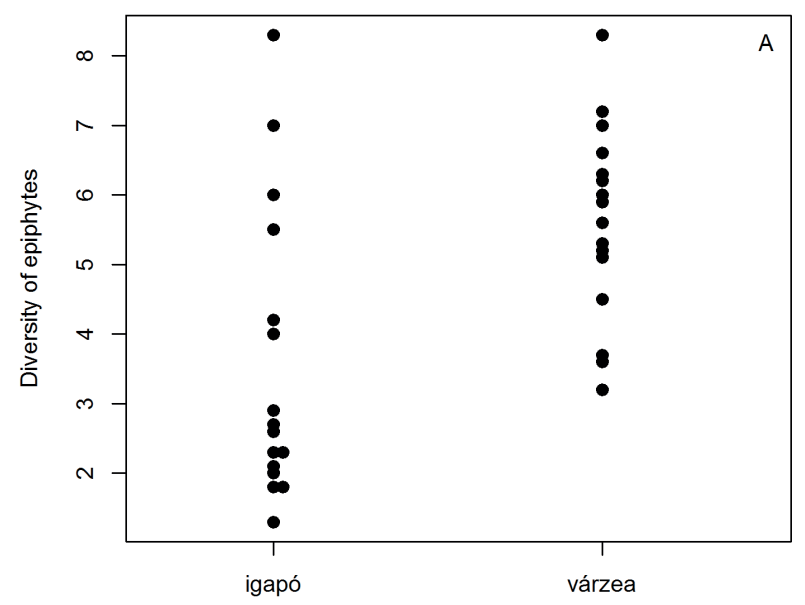

Várzea

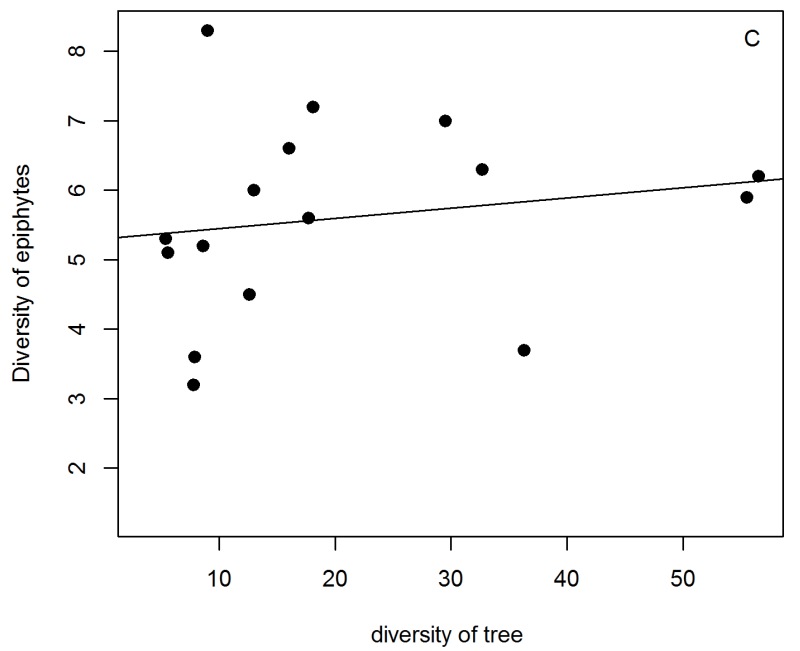

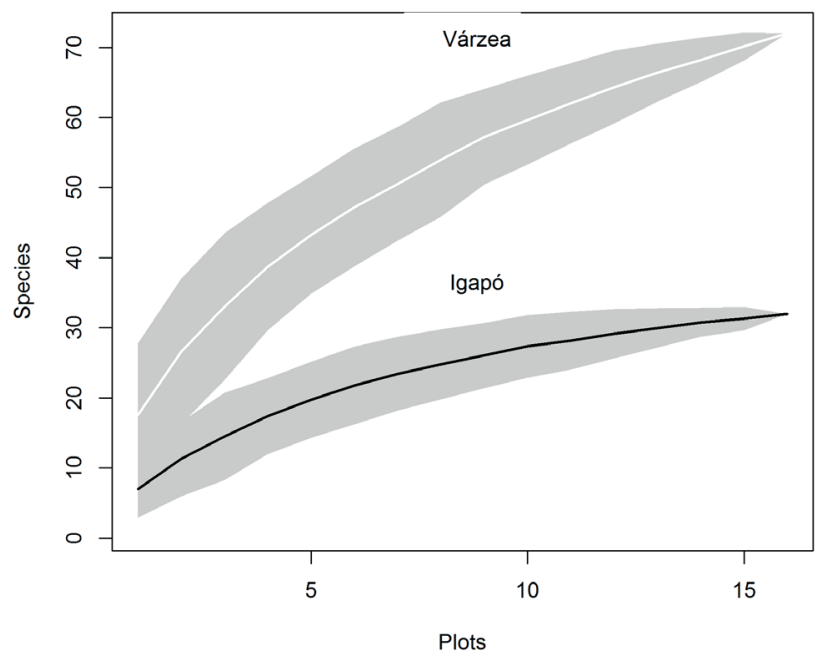

Figure 2. Rarefaction curves showing the sampling sufficiency in each environment.

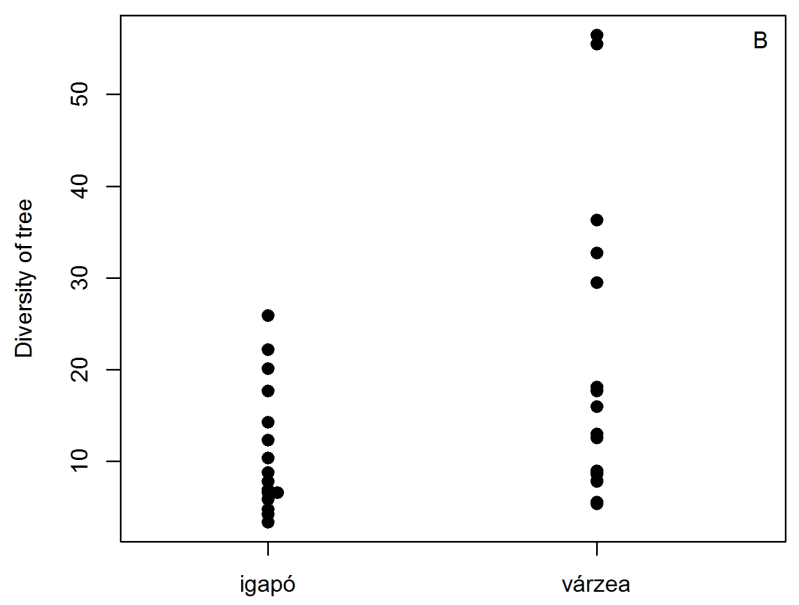

Igapó

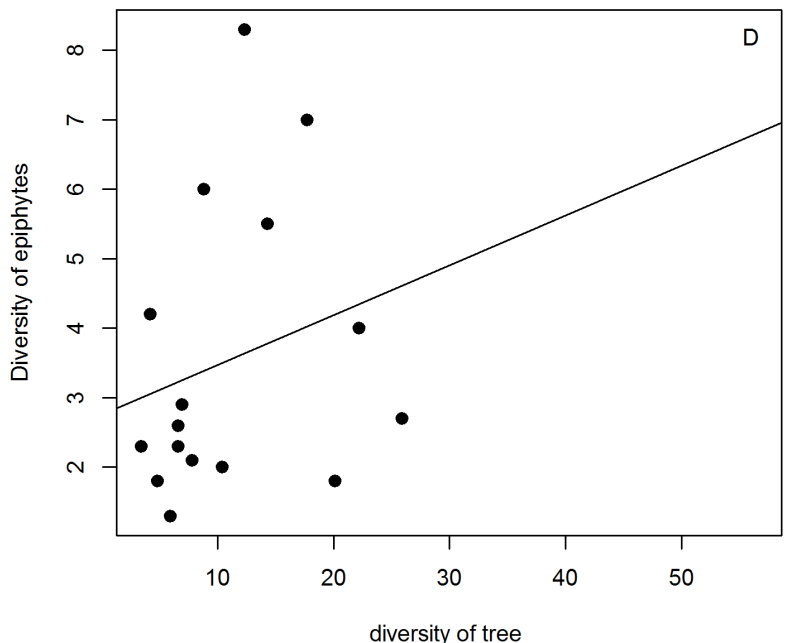

Figure 3. Difference of the diversity of epiphyte assemblages (A) and tree assemblages (B) in plot of varzea and igapó forest. of Central Amazonia. Despite a difference in diversity between the forests, diversity of trees did not influence diversity of epiphytes in the studied forests (C-D). 
the trees and vascular epiphyte. Várzea environments are characterized by relatively high nutritional richness and river dynamics that provide high habitat heterogeneity and proportionate higher diversity when compared to nutrient poor and low dynamic of the igapo river systems (Wittmann et al. 2012; Junk et al. 2015).

Differences in epiphyte diversity may be associated with differences in tree diversity between environments. Epiphytes are dependent on support structure, and they evolved a variety of ways to colonize various tree species and avoid competition. Consequentially, structural host preference of particular epiphytes means that the composition of local tree assemblages can potentially have a strong influence on epiphyte species assemblage composition, (Laube \& Zotz 2006; Burns \& Zotz 2010). This was shown by Zotz et al. (2014) who investigated canopy of a montane forest in Panama, and found that epiphytes cease to occupy certain habitats not because of climatic adversity, but due to the lack of adequate substrate for colonization. Other supporting evidence comes from observations that epiphyte diversity decreased in areas that suffered a reduction in the tree diversity of primary forest species, and where secondary forests dominated (Bartholott et al. 2001; Wolf 2005).

While vascular epiphytes are not attached to the soil, Gentry \& Dodson (1987) suggest that their richness and composition vary according to soil fertility, as occurs with other plant groups such as trees. In support of this, Boelter et al. (2014) demonstrated that soil phosphorus (P) concentration was the most important factor in explaining the vascular epiphyte richness of in Central Amazonian terra firme forest. Even though the differences in P levels between várzea and igapó forests are small, the proportion of this nutrient available to be passed from soil to trunk, branches and leaves is higher in várzea (Furch 1997). Of the $41 \mathrm{~kg} / \mathrm{ha}^{-1}$ of phosphorus present in igapó, only $4 \mathrm{~kg} /$ ha $^{-1}(9.7 \%)$ is passed to the above-ground plant biomass. In contrast, out of the $49 \mathrm{~kg} / \mathrm{ha}^{-1} \mathrm{P}$ in várzea soil, $24 \mathrm{~kg} /$ $\mathrm{ha}^{-1}(49.9 \%)$ is passed to the above-ground plant biomass (Furch 1997). Thus, it is expected that a greater amount of this nutrient is absorbed by epiphytes through lixiviation of rainwater passing along host tree stem and branches and/ or by the accumulation of humus in-between branches, which may explain the higher epiphyte species richness in várzea environment.

Nutrients might also be carried from the soil to the canopy by animals, especially invertebrates that perform vertical movements to avoid inundation (Adis \& Messer 1997). Martius (1997) observed that the canopy is the habitat most used by termites in várzea forests. All the trees we climbed in várzeas were occupied by termites or ants or both, while this is much less common in igapó trees. These animals use, at least as passageway, epiphyte species and thus might contribute carrying nutrients from the soil.
Vascular epiphytes occur at greater richness and abundance on trees with bigger diameters, because those have more substratum available for colonization (Flores-Palacios \& García-Franco 2006). Várzea forests have twice as much of wood and bark biomass as igapó (7.4 t/ ha ${ }^{-1}$ in várzea and $3.4 \mathrm{t} / \mathrm{ha}^{-1}$ in igapó) (Furch 1997), and consequently twice as much substratum available for epiphyte colonization. Large tree species unique in várzea such as Hura creptans, Piranea trifoliolata and Crisophyllum argenteum may increase the number of specific microhabitats available for colonization for epiphytes.

The family composition in the two environments followed a pantropical trend, with Orchidaceae dominant over other

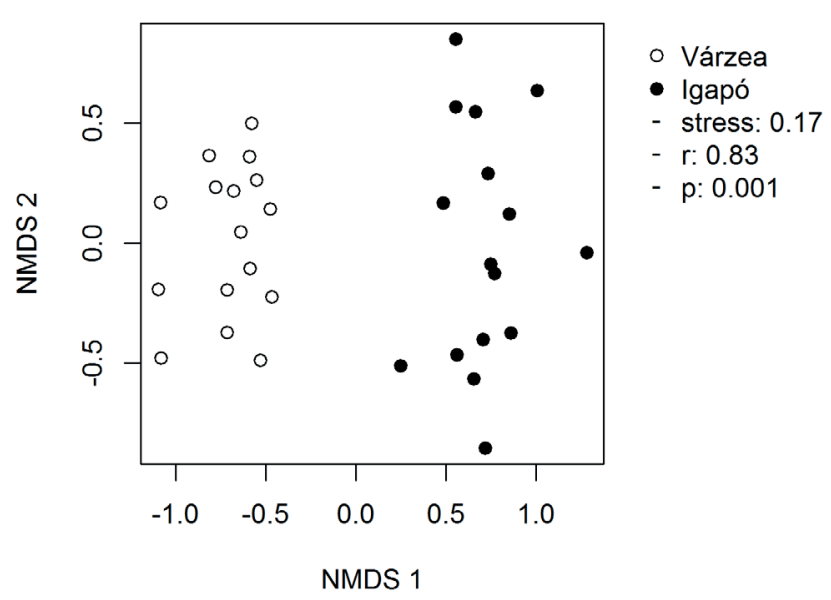

Figure 4. Non-metric Multidimensional Scaling (NMDS) showing the separation of the composition of epiphytic species between the várzea and igapó, floodplain forests indicating the existence of two distinct groups.

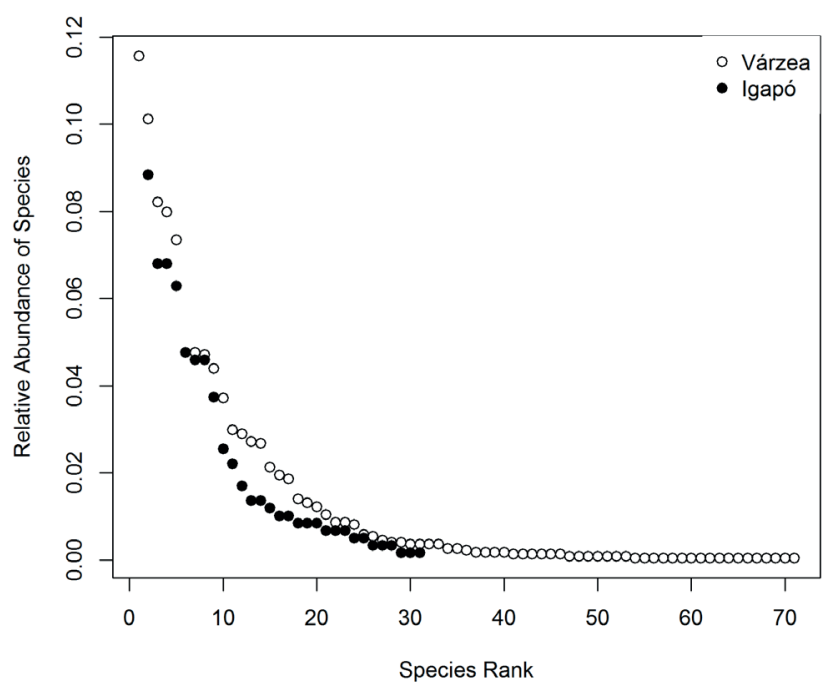

Figure 5. Abundance ranking of epiphyte species found in várzea and igapó forests in Central Amazonia. Black circles represent igapó species and empty circles várzea species. 
Table 2. Structural parameters of the 20 main vascular epiphyte species from várzea and igapó forests in Central Amazonia. Fai absolute frequency of epiphyte species on individual host trees; FRi - relative frequency of epiphyte species on individual host trees; $\mathrm{FAj}$ - absolute frequency of epiphyte species on specific host trees; $\mathrm{FRj}$ - relative frequency of epiphyte species on specific host trees; IVe - value of epiphytic importance.

\begin{tabular}{|c|c|c|c|c|c|c|c|c|c|c|c|}
\hline \multicolumn{6}{|c|}{ VÁRZEA } & \multicolumn{6}{|c|}{ IGAPÓ } \\
\hline Species & FAi & FRi & $\mathbf{F A j}$ & FRj & IVe & Species & FAi & FRi & FAj & FRj & IVe \\
\hline M. reptans & 45.26 & 13.69 & 59.78 & 10.54 & 12.12 & C. crassifolia & 32.12 & 21.73 & 53.70 & 19.34 & 20.54 \\
\hline P. rotundifolia & 33.68 & 10.19 & 50.00 & 8.81 & 9.50 & P. solimoesensis & 10.30 & 6.97 & 20.37 & 7.34 & 7.15 \\
\hline C. crassifolia & 24.74 & 7.48 & 38.04 & 6.70 & 7.09 & Philodendron sp. & 15.76 & 10.66 & 9.26 & 3.33 & 7.00 \\
\hline M. percusa & 19.47 & 5.89 & 33.70 & 5.94 & 5.92 & Orleanesia sp. & 8.48 & 5.74 & 16.67 & 6.00 & 5.87 \\
\hline P. polypodioides & 18.95 & 5.73 & 30.43 & 5.36 & 5.55 & C. cebolleta & 9.09 & 6.15 & 14.81 & 5.33 & 5.74 \\
\hline A. bomplantii & 14.21 & 4.30 & 23.91 & 4.21 & 4.26 & E.micronocturnum & 6.06 & 4.10 & 16.67 & 6.00 & 5.05 \\
\hline A. gracile & 10.00 & 3.03 & 19.57 & 3.45 & 3.24 & Clusia sp. & 6.67 & 4.51 & 14.81 & 5.33 & 4.92 \\
\hline A. angustifolium & 8.95 & 2.71 & 17.39 & 3.07 & 2.89 & P. stenophylla & 6.67 & 4.51 & 12.96 & 4.67 & 4.59 \\
\hline H. equitans & 10.00 & 3.03 & 15.22 & 2.68 & 2.85 & G. devoniana & 7.27 & 4.92 & 11.11 & 4.00 & 4.46 \\
\hline C. micrantun & 8.42 & 2.55 & 15.22 & 2.68 & 2.61 & P. acutatum & 4.85 & 3.28 & 14.81 & 5.33 & 4.31 \\
\hline C. uncata & 8.42 & 2.55 & 14.13 & 2.49 & 2.52 & E. nocturnum & 4.24 & 2.87 & 9.26 & 3.33 & 3.10 \\
\hline A. angustifolium & 7.37 & 2.23 & 15.22 & 2.68 & 2.46 & P. concreta & 3.03 & 2.05 & 9.26 & 3.33 & 2.69 \\
\hline Epiphilum sp. & 1.05 & 0.32 & 23.91 & 4.21 & 2.27 & C. bicornutum & 3.64 & 2.46 & 7.41 & 2.67 & 2.56 \\
\hline Monstera sp. & 7.89 & 2.39 & 10.87 & 1.92 & 2.15 & $V$. lineata & 4.24 & 2.87 & 3.70 & 1.33 & 2.10 \\
\hline Aechmea sp. & 6.84 & 2.07 & 11.96 & 2.11 & 2.09 & C. ulei & 2.42 & 1.64 & 5.56 & 2.00 & 1.82 \\
\hline E. rigidum & 6.84 & 2.07 & 11.96 & 2.11 & 2.09 & P. vespa & 1.82 & 1.23 & 5.56 & 2.00 & 1.62 \\
\hline C. angustifolium & 5.79 & 1.75 & 9.78 & 1.72 & 1.74 & A. serratum & 3.64 & 2.46 & 1.85 & 0.67 & 1.56 \\
\hline E. strobiliferum & 5.79 & 1.75 & 9.78 & 1.72 & 1.74 & C. violacea & 1.82 & 1.23 & 3.70 & 1.33 & 1.28 \\
\hline Philodendrum sp. & 5.26 & 1.59 & 7.61 & 1.34 & 1.47 & A. setigera & 1.21 & 0.82 & 3.70 & 1.33 & 1.08 \\
\hline S. spiculifera & 4.74 & 1.43 & 7.61 & 1.34 & 1.39 & B. martiana & 1.21 & 0.82 & 3.70 & 1.33 & 1.08 \\
\hline
\end{tabular}

families (i.e. Laube \& Zotz 2003; Wang et al. 2016). This tendency has been widely observed in Amazonian forests (Nieder et al. 2000; Pos \& Sleegers 2010; Obermüller et al. 2012; Quaresma \& Jardim 2014; Boelter et al. 2015), except for the study of Irume et al. (2013) in upland forests (terra firme forests), where Araceae was the most speciose family recorded. The development of velamen, pseudobulbs for water storage and the CAM metabolic pathway (Benzing 1990; Zotz 2004) are some of the adaptations given as the reasons for the success of orchids in colonizing tropical trees, which make them the epiphyte family with the highest number of species (Zotz 2013). Albeit highly diverse, orchid species were not abundant (see appendix), and the most abundant species were concentrated in few phorophyte species. This aggregated distribution is possibly linked to the dispersal limitations of many orchid species (Mondragon et al. 2012), or to the preference for specific tree species, as it is commonly registered for epiphyte assemblages (Burns \& Zotz 2010).

The holoepiphyte life-form, dominant in the studied areas, was also reported as predominant for tropical forests canopies (i.e. Kersten 2010; Zotz 2013), including Amazonian terra firme (Pos \& Sleegers 2010; Boelter et al. 2015) and coastal forests (restinga forests) (Quaresma \& Jardim 2014). Holoepiphytes are also dominant in forests of the Venezuelan and Colombian Amazon (Nieder et al. 2000; Benavides et al. 2011, respectively).

It is likely that seasonal inundation creates conditions of high humidity (Benavides et al. 2011). This fact, associated with a rapid propagation due to the extensive production of anemochoric seeds (Cascante-Marin 2006), may greatly facilitate holo-epiphyte establishment and growth. On the other hand, hemi-epiphytes produce fewer seeds (Benzing 1990), and often depend on other dispersers, especially birds and bats, to carry them to suitable germination sites. Annual inundation is also a factor that may limit the occurrence of hemi-epiphytes in both environments as, their post-germination roots subsequently reach the soil and capture nutrients. The greater number of hemiepiphytes species in várzea than igapó is probably related to the higher nutrient richness of soils in this ecosystem. Thus, even though inundation may be a limiting factor, our hypothesis is that the occurrence of species able to develop secondary roots would be advantageous, given the nutrient-rich soil.

\section{Structure}

The majority of locally rare species are almost always more abundant in another geographical area (Murray \& Lepschi 2004; Zotz 2007), making the concept of "rarity" and "abundant" somewhat arbitrary. An example from our study involves two aroid species (Philodendron billietiae and Philodendrum solimoesensis) which are very abundant in igapó, but which had only few individuals registered in várzea. Distinguishing species that are rare in all their distribution from species that are locally rare is fundamental for ecological studies that aim to assist conservation (Hercos et al. 2012). 
Of the species we recorded, $42 \%$ can be considered "rare", and $27 \%$ "abundant". The presence of many rare and few abundant species is a frequently reported pattern for vascular epiphyte assemblages (i.e., Nieder et al. 2000; Zotz 2007; Zotz \& Bader 2011), and is in accord with what Pitman et al. (2001) called the "homogeneity hypothesis". These authors stated that forests are dominated by a small number of species that form compositional "oligarchies" that are relatively constant across large geographical areas. The occurrence of oligarchic species in the arboreal assemblages has already been documented for other lifeforms (Pitman et al. 2001; Vormisto et al. 2004), including trees in várzea (Wittmann et al. 2006) and igapó forests (Montero et al. 2012). Oligarchies of species seem to be present in epiphyte assemblages in Amazonian forests, even so it is noteworthy that testing the homogeneity hypothesis was not the objective of this study. Nonetheless, future researches that aim specifically to verify the composition of epiphyte assemblages within great river basins may confirm this hypothesis.

Although the Orchidaceae had the greatest number of species, we found that species with the highest IVe were not orchids, but Gesneriads and Aroids in igapó, and Polypoids, Piperacids and Gesneriads in várzea. Irume et al. (2013) reported Guzmania lingulata (Bromeliaceae) and Philodendron linnaei (Araceae) in terra firme forest to have an IVe of $27 \%$. While Quaresma \& Jardim (2014) recorded Philodendrun acutatum, Anthurium pentaphylum and Philodendrum muricatum (Araceae) densities that together summed to almost $90 \%$ of all IVe in Amazonian restinga forests. Therefore, the results found for várzea and igapó may be part of a broader general pattern for Amazonian forests, where species orchids are more diverse. However, species from other families have a fundamental role, as their species, in addition to contributing large numbers of individuals, have broad distribution in the environment, so that they are involved in a large number of ecological interactions.

Species with high IVe are, according to Waechter (1998), are characterized by a high capacity for dispersal and colonization of different environments, strata, individuals and species of phorophytes. In this context, C. crassifolia had very high values for both forest types. The species has a number of adaptive strategies including fleshy leaves, mesophyll with water storing cells, and waxy cuticle for protection from the sun in the upper canopy, plus a high reproductive capacity that comes from perennial production of flowers and fruits (Kleinfeldt 1978) to enable a broad and successful colonization of the epiphytic environment. Additionally, this species is commonly found associated with ant gardens in the study area, and ants disperse $C$. crassifolia seeds to suitable germination sites, as well as increasing the species vegetative growth rates (Kleinfeldt 1978).

Microgramma reptans and Peperomia retundifolia also had elevated IVe values in várzea. These species have rhizomatous growth and a strong capacity for colonizing small branches in the forest (Zotz 2007). Philodendron solimoesensis, the species with second highest IVe in igapó, have a highly-developed pollination capacity, being visited by beetles that fly 50300m between plants (Gibernal et al. 1999). Nonetheless, apart from a scattering of such studies, little is known about the species and populations recorded in this study, which hampers the formation of viable inferences concerning the dominance of some species over others. Future studies on autoecology of Amazon floodplain epiphyte species are essential such questions are to be answered successfully.

\section{Conclusion}

Central Amazonian várzea and igapó forests are environments with vascular epiphyte assemblages of distinct composition, diversity and structure. Like the trees these habitats, their epiphytic flora show low similarity between ecosystems. Várzea forests have a considerably larger number of species and individual epiphytes than igapó, with the assemblage being so diverse that the sampling effort of this study was not enough to fully assay the composition and richness of this component of várzea ecosystem. In contrast, igapó is lower so that our sampling effort was satisfactory. As recorded for trees, where an high beta diversity has been reported in igapós, studies in further várzea and igapó forests may may refine, amplify and finesse the patterns reported in this study.

\section{Acknowledgements}

We acknowledge the Dr. Maria de Lourdes Soares for help in aroids identification, the Dr. Ana Kelly Koch for helping in Orchidaceae identification, the Dr. Micheline Silva for helping in Piperaceae identification, the Ms Gabriel Emiliano for help in identification Gesneriaceae and to Ms Sebastião Maciel for help in identification Pteridophytes. The CAPES for a Doctorate scholarship to the first author, the ICMBio and Instituto Mamirauá for logistical support, the CNPq for funding through the project PELD/MAUA Áreas Úmidas.

\section{References}

Adis J, Messner B. 1997. Adaptations to life under water: Tiger beetles and millipedes. In: Junk W. (ed.) The central amazon floodplain. Berlin, Springer-Verlag. p. 319-329.

Aguiar DPP. 2015. Influencia dos fatores hidro-edáficos na diversidade, composição florística e estrutura da comunidade arbórea de igapó no Parque Nacional do Jaú, Amazônia Central. MSc Thesis, Instituto Nacional de Pesquisas da Amazônia, Manaus.

APG III. 2009. An update of the Angiosperm Phylogeny Group classification for the orders and families of flowering plants: APG III. Botanical Journal of the Linnean Society 161: 105-121.

Ayres JM. 1993. As matas de várzea do Mamirauá, médio rio Solimões. Brasília, CNPq - Programa Trópico Úmido e Sociedade Civil Mamirauá. 
Barthlott W, Schmit-Neuerburg V, Nieder J, Engwald S. 2001. Diversity and abundance of vascular epiphytes: a comparison of secondary vegetation and primary montane rain forest in the Venezuelan Andes. Plant Ecology 152: 145-156.

Benavides AM, Vasco A, Duque AJ, Duivenvoorden JF. 2011. Association of vascular epiphytes with landscape units and phorophytes in humid lowland forests of Colombian Amazonia. Journal of Tropical Ecology 27: 223-237.

Benzing DH. 1990. Vascular epiphytes. New York, Cambridge University Press.

Boelter CR, Dambros CS, Nascimento HEM, Zartman CE. 2014. A tangled web in tropical tree-tops: effects of edaphic variation, neigh bourhood phorophyte composition and bark characteristics on epiphytes in a central Amazonian forest. Journal Vegetation Science 25: 1090-1099.

Burns KC, Zotz G. 2010. A hierarchical framework for investigating epiphyte assemblages: networks, meta-communities, and scale. Ecology 91: 377-385.

Cascante-Marín A, Meijenfeldt N, Leeuw HMH, Wolf JHD, Oostermeijer JGB, Nijs JCM. 2009. Dispersal limitation in epiphytic bromeliad communities in a Costa Rican fragmented montane landscape. Journal of Tropical Ecology 25: 63-73.

Cruz J. 1994. Aspectos ecológicos das Orchidaceae de terra firme do Campo Petrolífero do Rio Urucu, Amazonas - Brasil. MSc Thesis, Instituto Nacional de Pesquisas da Amazônia Manaus.

Cruz J, Braga PIS. 1997. Aspectos Taxonômicos e Fenológicos de Orchidaceae Epífitas no Campo Petrolífero do Rio Urucu, Amazonas - Brasil. Revista da Universidade do Amazonas, Série: Ciências Biológicas 1: 1-134.

Ferreira LV. 2000. Effects of flooding duration on species richness, floristic composition and forest structure in river margin habitat in Amazonian black water floodplain forests: implications for future design of protected areas. Biodiversity and Conservation 9: 1-14.

Fisher RA, Corbet AS, Williams CB. 1943. The relation between the number of species and the number of individuals in a random sample of an animal population. Journal Animal Ecology 12: 42-58.

Flora do Brasil 2020 - em construção. Lista de Espécies da Flora do Brasil. Rio de Janeiro, Jardim Botânico do Rio de Janeiro. http://floradobrasil. jbrj.gov.br/ . 13 Jun. 2017.

Flores-Palacios A, García-Franco G. 2006. The relationship between tree size and epiphyte species richness: testing four different hypotheses. Journal of Biogeography 33: 323-330.

Fontoura T, Rocca MA, Schilling AC, Reiner F. 2009. Epífitas da floresta seca da reserva ecológica estadual de Jacarepiá, Sudeste do Brasil: relações com a comunidade arbórea. Rodriguésia 60: 171-185.

Furch K. 1997. Chemistry of várzea and igapó soils and nutrient inventory of their floodplain forests. In: Junk WJ. (ed.) The Central Amazon floodplain: Ecology of a pulsing system. Berlin, Springer. p. 47-68.

Gentry A, Dodson CH. 1987. Diversity and biogeography of Neotropical vascular epiphytes. Annals of the Missouri Botanical Garden 74: 205-233.

Gibernau M, Barabé D, Cerdan P, Dejean A. 1999. Beetle pollination of Philodendron solimoesense (Araceae) in French Guiana. International Journal of Plant 160: 1135-1143.

Gotelli NJ, Colwell RK. 2010. Estimating species richness. In: Magurran AE, McGill BJ. (eds.). Biological diversity: Frontiers in measurement and assessment. Oxford, Oxford University Pres. p. 39-54

Gottsberger G, Morawetz W. 1993. Development and distribution of the epiphytic flora in an Amazonian savanna in Brazil. Flora 188: 145-151.

Haugaasen T, Peres CA. 2006. Floristic, edaphic and structural characteristics of flooded and unflooded forests in the lower Rio Purus region of central Amazonia, Brazil. Acta Amazonica 36: 25-36

Hercos AP, Sobansky M, Queiroz HL, Magurran, AE. 2012. Local and regional rarity in a diverse tropical fish assemblage. Proceedings of the Royal Society 280: 20122076.

Inuma JJ. 2006. Comparação na diversidade e estrutura das comunidades de plantas lenhosas da terra firme, várzea e igapó do Amaná, Amazônia Central. PhD Thesis, Instituto Nacional de Pesquisas da Amazônia, Manaus.

Irion G. 1984. Sedimentation and sediments of Amazon rivers and evolution of the Amazon landscape since Pliocene times. In: Sioli
H. (ed.) The Amazon - limnology and landscape ecology of a mighty tropical river and its Basin. Boston, Lancaster, The Hague. p. 201-214. Irume MV, Moraes MCLS, Zartman CE, Amaral IL. 2013. Floristic composition and community structure of epiphytic angiosperms in a terra firme forest in central Amazonia. Acta Botanica Brasilica 27: 378-393.

Junk WJ, Bayley PB, Sparks RE. 1989. The flood pulse concept in riverfloodplain systems. Canadian Journal of Fisheries and Aquatic Sciences 106: 110-127.

Junk WJ, Piedade MTF, Schöngart J, Cohn-Haft M, Adeney MJ, Wittmann F. 2011. A classification of major naturally-occurring Amazonian lowland wetlands. Wetlands 31: 623-640.

Junk WJ, Wittmann F, Schongart J, Piedade MTF. 2015. A classification of the major habitats of Amazonian black-water river floodplains and a comparison with their white-water counterparts. Wetlands Ecology and Management 23: 677-693.

Kersten RA. 2010. Epífitas vasculares - História, participação taxonômica e aspectos relevantes com ênfase na Mata Atlântica. Hoehnea 37: 9-38.

Kleinfeldt SE. 1978. Ant-gardens: the interaction of Codonanthe crassifolia (Gesneriaceae) and Crematogaster longispina (Formicidae). Ecology 59: 449-456.

Laube S, Zotz G. 2003. Which abiotic factors limit vegetative growth in a vascular epiphyte? Functional Ecology 17: 598-604.

Laube S, Zotz G. 2006. Long-term changes in the epiphyte vegetation of the palm, Socratea exorrhiza. Journal of Vegetation Science. 17: 307-314.

Mari MLG, Toledo JJ, Nascimento HME, Zartman CE. 2016. Regional and fine scale variation of holoepiphyte community structure in Central Amazonian white-sand forests. Biotropica 48: 70-80.

Martius C. 1997. The Termites. In: Junk W. (ed.) The central amazon floodplain. Berlin, Springer-Verlag. p. 361-371.

Melack JM, Hess LL. 2010. Remote sensing of the distribution and extent of wetlands in the Amazon Basin. In: Junk WJ, Piedade MTF, Wittmann F, Schöngart J, Parolin P. (eds.). Amazonian floodplain forests: Ecophysiology, biodiversity and sustainable management. Serie Ecological Studies. Dordrecht, Springer Netherlands. p. 44-58.

Mondragón D, Valverde T, Hernandez-Apolimar M. 2012. Population ecology of epiphytic angiosperms: A review. Tropical Ecology 56: 01-39.

Montero CJ, Piedade MTP, Wittmann F. 2012. Floristic variation across $600 \mathrm{~km}$ of inundation forest (Igapó) along the Negro River, Central Amazonia. Hydrobiologia 729: 229-246.

Mueller-Dombois D, Ellenberg H. 1974. Aims and methods of vegetation ecology. New York, John Wiley and Sons.

Murray BR, Lepschi BJ 2004. Are locally rare species abundant elsewhere in their geographical range? Austral Ecology 29: 287-293.

Nieder J, Engwald S, Klawun M, Barthlott W. 2000. Spatial distribution of vascular epiphytes (including hemiepiphytes) in a lowland amazonian rain Forest (Surumoni Crane Plot) of southern Venezuela. Biotropica 32: 385-396.

Obermüller FA, Silveira M, Salimon CI, Daly DC. 2012. Epiphytic (including hemiepiphytes) diversity in three timber species in the southwestern Amazon, Brazil. Biodiversity and Conservation 21: 565-575.

Pitman NCA, Terborgh JW, Silman MR, et al. 2001. Dominance and distribution of tree species in upper Amazonian terra firme forests. Ecology 82: 2101-2117.

Plano de Gestão. 2014. Reserva de Desenvolvimento Sustentável Mamirauá - RDSM. - 3rd. edn. rev. e ampl. - Tefé, IDSM.

Pos ET, Sleegers ADM. 2010. Vertical distribution and ecology of vascular epiphytes in a lowland tropical rain forest of Brazil. Boletim do Museu Paraense Emílio Goeldi, Ciências Naturais 5: 335-344.

Prance GT. 1979. Notes on the vegetation of Amazonia. 3. The terminology of Amazonian forest types subject to inundation. Brittonia 31:26-38.

Quaresma AC, Jardim MAG. 2014. Floristic composition and spatial distribution of vascular epiphytes in the restingas of Maracanã, Brazil. Acta Botanica Brasilica 28: 68-75.

R Development Core Team. 2011. R: A language and environment for statistical computing. Vienna, R Foundation for Statistical Computing. http://www.R-project.org/. 
Ribeiro JELS, Hopkins MJG, Vicentini A, et al. 1999. Flora da Reserva Ducke: Guia de identificação das plantas vasculares de uma floresta de terra-firme na Amazônia Central. Manaus, INPA.

Sanford WW. 1968. Distribution of epiphytic orchids in semi-deciduous tropical forest in southern Nigeria. Journal of Ecology 56: 697-705.

Schuettpelz E, Trapnell DWT. 2006. Exceptional epiphyte diversity on a single tree in Costa Rica. Selbyana 27:65-71.

Sioli H. 1984. The Amazon and its main affluents: hydrography, morphology of the river courses and river types. In: Sioli H. (ed.) The Amazon. Limnology and landscape ecology of a mighty tropical river and its basin. Dordrecht, Dr. W. Junk Publishers. p. 127-165.

Steege H, Cornellisen JHC. 1989. Distribution and Ecology of vascular epiphytes in Lowland Rain Forest of Guyana. Biotropica 21: 331-339.

Vormisto J, Tuomisto H, Oksanem J. 2004. Palm distribution patterns in Amazonian rainforests: What is the role of topographic variation? Journal of Vegetation. Science. 15: 485-494.

Waechter JL. 1998. Epifitismo vascular em uma floresta de restinga do Brasil Subtropical. Revista Ciência e Natura 20: 43-66.

Wang X, Long W, Schamp BS, et al. 2016. Vascular epiphyte diversity differs with host crown zone and diameter, but not orientation in a tropical Cloud Forest. PLoS ONE 11(7). e0158548. https://doi.org/10.1371/ journal.pone. 0158548

Wittmann F, Anhuf D, Junk WJ. 2002. Tree species distribution and community structure of central Amazonian várzea forests by remotesensing techniques. Journal of Tropical Ecology, 18: 805-820

Wittmann F, Junk WJ, Piedade MTF. 2004. The várzea forests in Amazonia: flooding and the highly dynamic geomorphology interact with natural forest succession. Forest Ecology and Management 196: 199-212. Wittmann F, Schöngart J, Montero JC, et al. 2006. Tree species composition and diversity gradients in white-water forests across the Amazon basin. Journal of Biogeography 33: 1334-347.

Wittmann F, Schöngart J, Junk WJ. 2010. Phytogeography, species diversity, community structure and dynamics of Amazonian floodplain forests. In: Junk WJ, Piedade MTF, Wittmann F, Schöngart J, Parolin P. (eds.) Amazonian floodplain forests: ecophysiology, biodiversity and sustainable management. Ecological Studies. p. 61-102.

Wittmann F, Householder E, Piedade MTF, et al. 2012. Habitat specificity, endemism and the neotropical distribution of Amazonian white-water floodplain trees. Ecography 36: 690-707.

Wolf JHD. 2005. The response of epiphytes to anthropogenic disturbance of pine-oak forests in the highlands of Chiapas, México. Forest Ecology and Management 212: 376-393.

Zotz G. 2004. How prevalent is Crassulacean acid metabolism among vascular epiphytes? Oecologia 138: 184-192.

Zotz G. 2007. Johansson revisited: the spatial structure of epiphyte assemblages. Journal of Vegetation Science 18: 123-130.

Zotz G. 2013. The systematic distribution of vascular epiphytes - a critical update. Botanical Journal of the Linnean Society Soc. 171: 453-481.

Zotz G, Mendieta-Leiva G, Wagner K. 2014. Vascular epiphytes at the treeline - composition of species assemblages and population biology. Flora 209: 385-390.

Zuquim G, Costa RCF, Prado J, Tuomisto H. 2008. Guia de samambaias e licófitas da REBIO Uatumã - Amazônia Central. Manaus, INPA. 